\title{
遷音速流れにおける 2 次元楕円翼の抵抗および揚力変動の 制御に関する CFD 解析*1 \\ CFD Analysis of Control of Drag and Lift Oscillation on 2-Dimensional Elliptical Airfoil in Transonic Flow
}

\author{
海 田 武 司*2 • 中 村 佳 朗*2
}

Takeshi KAIDEN and Yoshiaki NAKAMURA

Key Words : Elliptical Airfoil, Flow Control, CFD, Drag and Lift Oscillation Reduction

\begin{abstract}
The control of drag and lift oscillation around a two-dimensional elliptical airfoil in a transonic regime is numerically investigated in the present study. In our laboratory, experimental researches on the control of both drag and lift oscillation around a circular cylinder, a square cylinder and an elliptical airfoil have been carried out, using small tabs. The objective of the present research is to make clear the detailed mechanism of reduction in drag and lift oscillation about the elliptical airfoil. As a result, it was found that small tabs make a virtual shape, and that the tabs push separation vortices, which cause the base drag, away from the airfoil. In addition, streamlines over the tabs are not largely curved in the wake. Therefore, the strength of shock waves produced on the airfoil is weakened, leading to a reduction in lift oscillation.
\end{abstract}

1.は じめ に

円柱や翼型の後流に見られるカルマン渦が周期的に振動 することは良く知られており，この現象についてはこれま で数多くの研究がなされてきている.この背景には, 単に 物理的な興味のみならず, 実際の応用においても，この非 定常現象がこれまで種々の悪影響を及ぼしてきていること がある.具体的には, カルマン渦は振動現象を発生させ , 構 造物と連成してフラッタ現象を誘起する . 低速域では大規 模な橋梁がこのカルマン渦により破壊されたり, また高速 域では飛行している航空機や宇宙機の機体が, 振動現象に より破損したりする、特に, 低速域から発生するカルマン 渦に加えて, 高速域で発生する衝撃波が連成して形成され る流れ場は複杂倠な挙動を示すため, 航空機・宇宙機設計に は十分な配慮が必要である。

このような流れ場の制御方法の一つに，対象物体にデバ イスを取り付け, 対象物体まわりの流れを変化させる方法 がある．いわゆる流れ制御である . これに関する有名な研 究としては, Roshko ${ }^{1)} や A p e l t ~ ~^{2)}$ による円柱の後流にス プリッタプレートを取り付け, 剝離渦振動や抵抗を減少さ せる研究がある . これらの研究は, 低速流れ場中の, 円柱 上面および下面から放出されるせん断層がお互いに干渉し 相互の剝離渦を巻き込む周期的な振動現象をスプリッタプ レートにより阻止させるものである .

一方, 本研究室では, 遷音速流れ場中で, 実機適用を念

\footnotetext{
*1 (C) 2004 日本航空宇宙学会

平成 15 年 11 月 24 日原稿受理

*2 名古屋大学大学院工学研究科航空宇宙工学専攻
}

頭に，より実現性の高いデバイスとして比較的小さいタブ を取り上げ，これを対象物体に取り付けた場合の研究を重 ねてきた . 遷音速領域では , カルマン渦による周期的振動 に加え，衝撃波が干渉するため，現象が複雑になる．これま での本研究室の遷音速風洞試験から，円柱や角柱の物体表 面にタブを取り付けると，抵抗低減や揚力変動抑制が可能 であることが確認された ${ }^{3,4)}$.このような小さなデバイスに は, 仮想形状 (Virtual Shape) 効果があり，また，楕円翼 においても，同樣な効果が存在することも確認されている5). 本研究では，楕円翼を対象物体として，風洞試験で確認 された物理現象のメカニズムを CFD 解析により検証する とともに, 風洞試験で実施していないマッハ数や取付け位 置等を幅広く変えて，新しい知見を得ることを目的とする．

\section{2. 計 算 内 容}

2.1 計算対象 計算対象は, 本研究室の風洞試験で採 用された, 主流方向と光の垂直方向の比が約 $2: 1$ の楕円翼 である . 風洞試験模型の実寸は流れ方向長さが $41 \mathrm{~mm}$, 垂 直方向長さが $21 \mathrm{~mm}$ である .また，流れ場を制御するため のタブの高さは $3 \mathrm{~mm}$ に固定し, 兴の取付け位置は翼後縁 より $4 \mathrm{~mm}$ (タイプ A) , $3 \mathrm{~mm}$ (タイプ B) , $2 \mathrm{~mm}$ (タイ プ C), $1 \mathrm{~mm}$ (タイプ D) の 4 種類とした (第 1 図).

2.2 計算格子 計算格子は代数的手法で生成され, C 型 単一格子である (第 2 図). 物体面上の格子点数は上下合わ せて 370 点 (タブ無しの場合は 300 点) で, 後流部分も含 めて物体表面に沿う方向に 599 点 (タブ無しの場合は 501 点）, 物体から離れる方向に 150 点, 合計約 90,000 点（タ ブ無しの場合は約 75,000 点) の計算格子を使用した . 


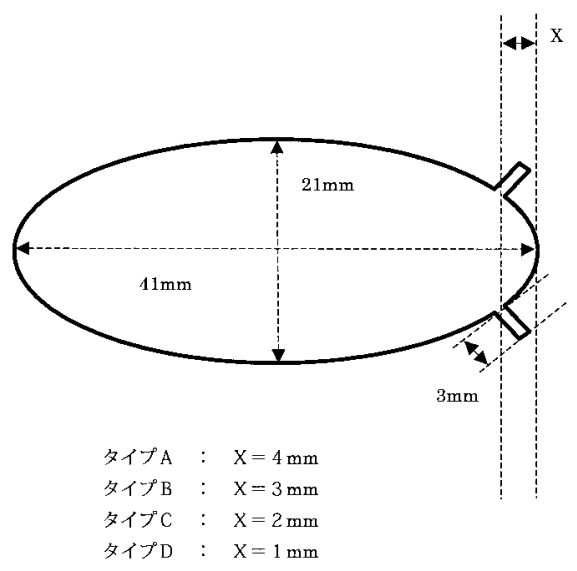

第 1 図 計算対象概要図

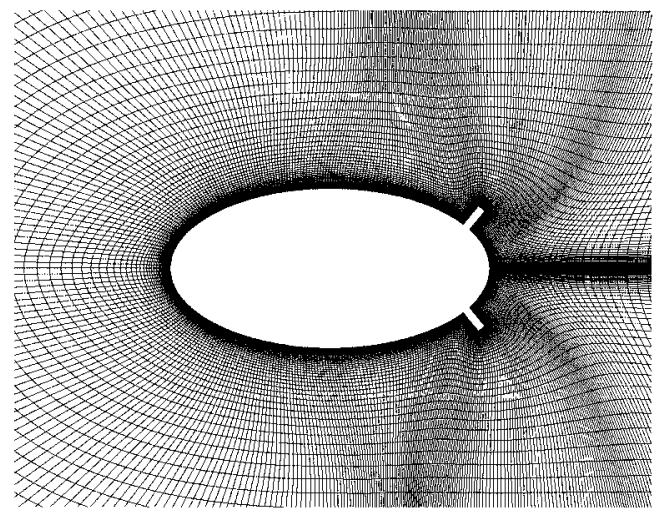

第 2 図計算格子 (タイプ B)

2.3 計算手法 支配方程式は 2 次元薄層ナビエ・ストー クス方程式で, 対流項には Roe の風上差分に MUSCL に よる高精度化 ${ }^{6)}$ を組み込んでいる．時間積分は LU-ADI 法を適用し, 計算開始時は局所時間刻み幅法で収束を加速 して，途中から全格子点一定時間刻み幅法で非定常計算を 行っている. 兴の際，時間精度を確保するために，時間刻 み幅を十分小さくしている．また，流れ場は非定常である ため，ここで示す計算結果は全て時間平均化されている． さらに，流れ場は乱流と考え，剝離現象を比較的精度良く， かつ効率的に捉えるために, Baldwin-Lomax 代数モデル7) に Degani-Schiff の修正 ${ }^{8)}$ を加えた乱流モデルを使用して いる。

2.4 計算条件 計算条件として, 迎角は $\alpha=0^{\circ}$ に固定 し, マッハ数は $M=0.4 \sim 0.75$ までの範囲から 9 点を選択 した . また ,レイノルズ数は風洞試験と同じ $R e=4.5 \times 10^{5}$ (翼弦長基準) とした。

\section{3. 風洞試験結果との比較・検証}

名古屋大学航空宇宙工学教室が所有する計測部 $0.4 \mathrm{~m}$ (高 さ） $\times 0.3 \mathrm{~m}$ (奥行き) の遷音速風洞 $\left.{ }^{9}\right)$ で実施した楕円翼の 風洞試験結果と比較しながら，CFD 解析結果を検証する。 本論文の空力係数は, 翼弦長を代表長さとして無次元化さ れている.

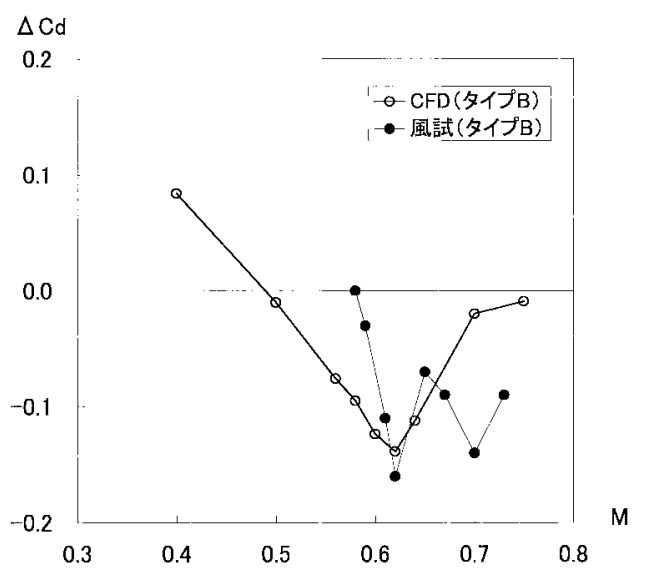

第 3 図 CFD と風試の抵抗係数差分比較

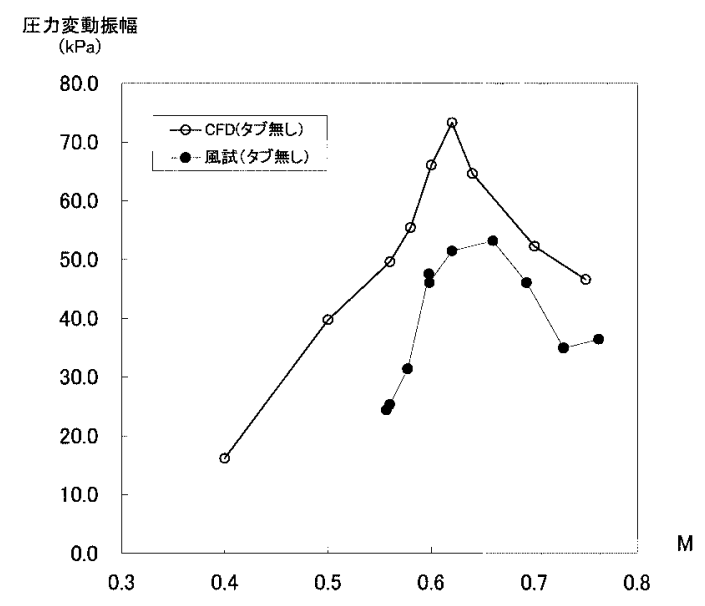

第 4 図 CFD と風試の圧力变動振幅比較

3.1 抵抗係数の変化 CFD 解析および風洞試験におい て , 各マッ八数における棈円翼のタブ有りと無しの場合で の抵抗係数の差を第 3 図に示す.タブは後縁から $3 \mathrm{~mm}$ の 位置にあるタイプ B を用いている. CFD 解析は 2 次元で 風洞試験は 3 次元であるため定量的には困難であるが, 定 性的には両者の傾向は類似している．すなわち，CFD解析 および風洞試験のいずれにおいても，タブを取り付けるこ とにより, $M=0.62$ 近傍て抵抗係数が最も減少している. 詳細は, 4 章と 5 章で述べる。

3.2 後縁圧力変動振幅の变化 次に, 棈円翼後縁近傍 の圧力変動の振幅について, 各マッ八数での CFD 解析と 風洞試験の比較を第 4 図に示す．振幅の評価は最大值と最 小値の差 (Peak to Peak) で行い, 試験模型の圧力孔は後 縁から $2 \mathrm{~mm}$ 上流の下面にある. 風洞試験では, マッ八数 を上げると振幅か増大し， $M=0.65$ を超えると再び減少 する.つまり， $M=0.65$ 近傍で振幅が最大となる . 一方， $\mathrm{CFD}$ 解析においても， $M<0.62$ ではマッハ数とともに 振幅か増大し， $M>0.62$ では振幅は減少する．すなわち， $M=0.62$ で振幅が最大となる特性を示す. 圧力変動振幅 值は CFD の方が若干大きいが, 風洞試験でも $M=0.65$ 付近て振幅が最大となっており，両者の対応は定性的に合っ ている. 


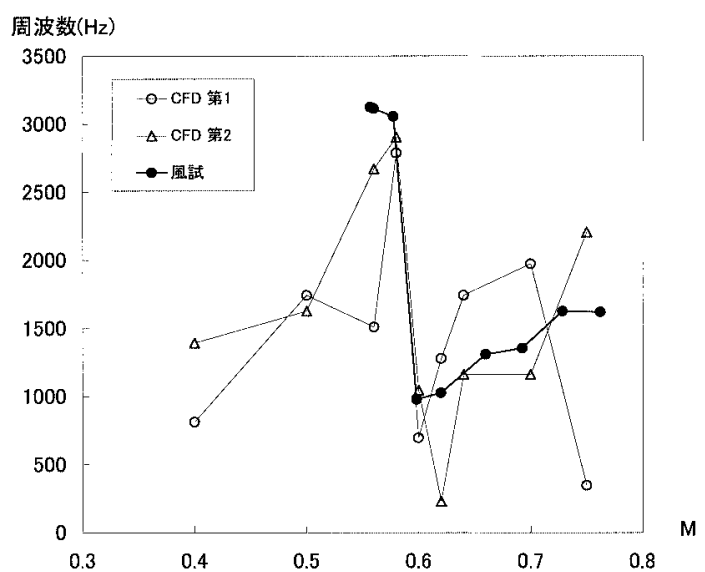

第 5 図＼cjkstart風試と CFD の圧力変動周波数比較（タブ無し）

ちなみに $M=0.62 〜 0.65$ を中心に後縁圧力振動が大き くなる原因は , 後述する第 12 図の密度勾配の時間変化か らもわかるように，剝離渦はマッハ数が増加すると強くな るが, あるマッハ数を超えると衝撃波が強くなり, 剝離流 は衝撃波の根元から直線的に後方に延びるため，後縁圧力 への影響が減少するためと考えられる。

3.3 後縁圧力変動周波数の変化 さらに, 各マッ八数に おける楕円翼後縁近傍の圧力変動周波数 (圧力変動ピーク 值が最も大きい周波数 : 第 1 周波数) の CFD 解析と風洞 試験の比較を第 5 図に示す . 圧力の計測点は前節と同じで ある. CFD 解析における周波数解析では, 計算時間の関係 上十分長い時間間隔でのサンプリングができないため, 周 波数解像度は十分とは言えない. 弚こで, 周波数解析結果 においては, 第 2 周波数 ( 2 番目にピークが大きい周波数) も同時に図中に示す. 風洞試験では， $M \leqq 0.58$ では周波 数が $3,000 \mathrm{~Hz}$ 程度となっているが, $M=0.60$ で周波数 が急激に減少し， $1,000 \mathrm{~Hz}$ 程度となる． $M \geqq 0.62$ では周 波数が徐々に上昇し，1,300〜 $1,600 \mathrm{~Hz}$ 程度となる．一方， $\mathrm{CFD}$ 解析では，第 1 周波数と第 2 周波数でマッハ数の高 いところで若干傾向は違うが, $M=0.58$ で周波数が最大 となり， $M=0.60$ では急激に周波数が減少する. CFD 解 析と風洞試験の両方とも，この $M=0.60$ での周波数の急 激な落ち込みが見られ, 定性的には良く対応している.こ の落ち込みの原因は, 前節同樣, カルマン渦と衝撃波の干 渉と考えられる (第 12 図参照). マッハ数か増加するとカ ルマン渦と衝撃波が干渉してそのカルマン渦は上下に大き く振られるとともに, 後縁からの距離か漓隹れて後縁圧力へ の影響が小さくなる. 光のため, 後縁圧力は周波数が小さ くなると思われる .

以上より, 抵抗係数, および表面圧力変動の振幅と周波 数について, 風洞試験と CFD 解析を比較し, CFD 解析が 概ね妥当な結果を与えることを確認した．

\section{CFD 解析の結果概要}

4.1 抵抗係数の変化 マッハ数を $M=0.40$ から 0.75 まで変化させたときの抵抗係数の変化について, 第 6 図 $\mathrm{a}$

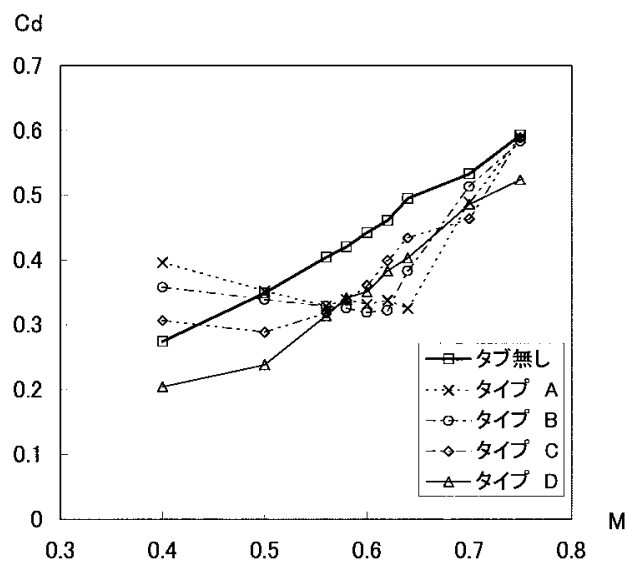

第 6 図 (a) 抵抗係数の比較

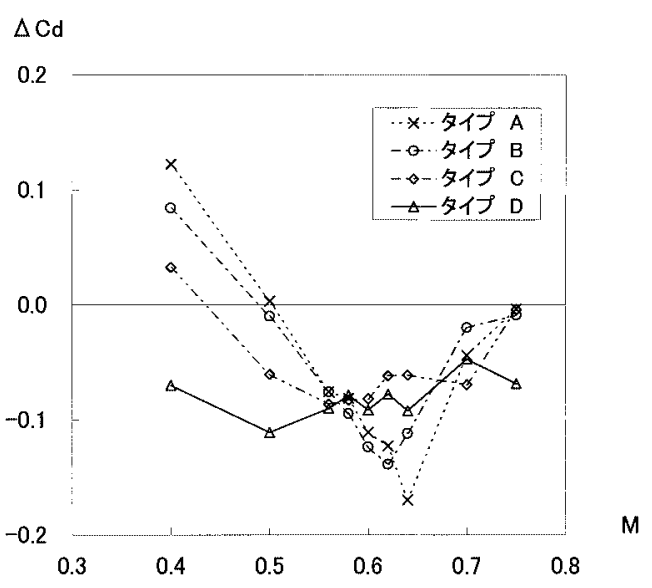

第 6 図 (b) 抵抗係数差分の変化

に抵抗係数炎のものを, 第 6 図 b にタブ有りの場合からタ ブ無しの場合を引いた抵抗係数差分を示す.

抵抗係数は, タブ無しの場合には, マッハ数とともに増 加する (第 6 図 a). 後述するように , マッハ数か増加する と翼面上に衝撃波か現われ, 关の影響で楕円翼の後半部で ほぼ剝離した流れ場となる . 谷の結果 , 圧力回復が困難とな り, 抵抗係数か増大する . また, 文献 10)によると, 非圧縮 領域においては, 今回の楕円翼形状およびレイノルズ数で は抵抗係数が 0.2 との実験結果があり, 本解析結果がほぼ妥 当と言える.さて，タイプ $\mathrm{A}, \mathrm{B}, \mathrm{C}$ の場合， $M=0.40$ で はタブを付けると抵抗係数は増加する .さらにマッハ数を 上げると抵抗係数は減少し, タイプ A, Bでは $M=0.60$ 0.65 , タイプ C では $M=0.5$ で極小值をとる $. M=0.75$ になると，再び抵抗係数はタブ無しの場合と同程度となる。 一方, タブが最も後縁に近いタイプDでは, マッハ数とと もに抵抗係数が単調に増加するというタブ無しの場合と同 じ傾向を示すが, 兴の值はいずれのマッハ数においてもタ ブ無しの場合より減少している．

第 6 図 b の抵抗係数差分を見ると，タイプ A , B では，

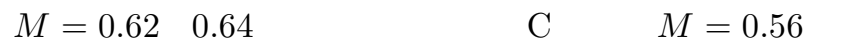
抵抗係数の低減効果が最大となる．一方，タイプ D では， 全てのマッハ数で，抵抗係数の低減効果が見られる．これ らの中で, タイプ A で $M=0.64$ の場合が, 最大の抵抗減 


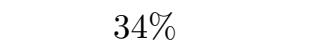

4.2 揚力係数変動振幅の変化 揚力係数变動の最大値 と最小值の差 $\Delta C l$ (Peak to Peak) とマッ八数の関係を第 7 図に示す . タブが無い場合には, 今回計算したマッハ数 の範囲ではマッ八数とともに減少する傾向にあり, $\Delta C l=$ 1.5〜2.3 となる.一方, タブを付けた場合には, いずれの タブ取付け位置においても，またいずれのマッハ数におい

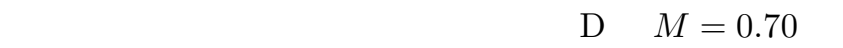
少し揚力係数変動が大きくなる程度) .

4.3 揚力係数变動周波数の変化 揚力係数変動の周波 数とマッハ数の関係を第 8 図に示す .この图では, 周波数 解析において 2 番目に大きい変動値と僅差の場合でも，揚 力係数変動值が最大となる周波数 (第 1 周波数) をプロッ トしているため, 周波数が急激に変化するように見える場 合がある . また，他の風洞試験では，風速 $10 \mathrm{~m} / \mathrm{s}$ の低速領 域において本研究対象とほぼ同じ縱横比をもつ楕円翼が発 生する渦振動のストローハル数は $0.27^{11)}$ との報告がある. これを $M=0.40$ において有次元換算をすると約 $1,840 \mathrm{~Hz}$ となり, 本 CFD 解析結果の約 $1,400 \mathrm{~Hz}$ と概ね妥当な結果 となっている．

3.3 節の後縁圧力変動とは異なり, タブの無い場合には， $M=0.50 \sim 0.60$ を除いて, 揚力係数変動周波数はマッハ

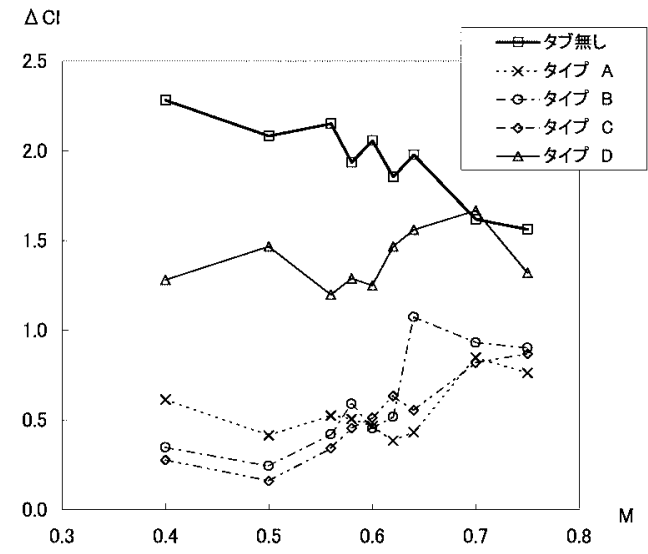

第 7 図 揚力係数変動振幅の変化

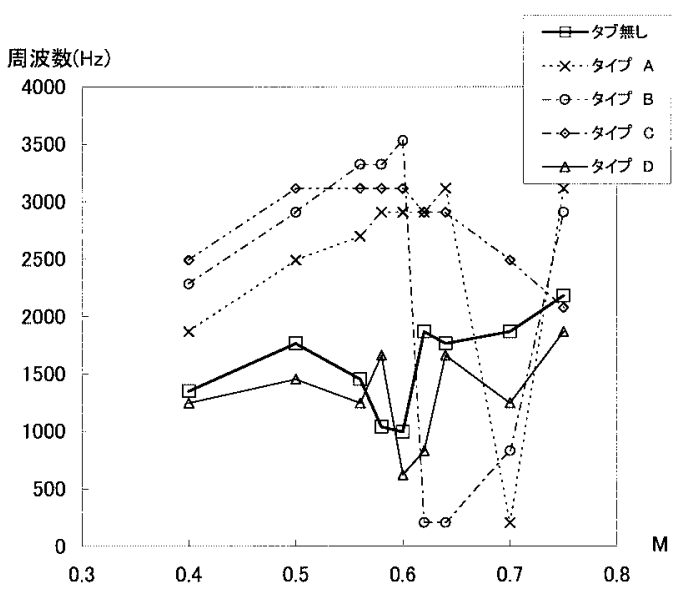

第 8 図 揚力係数変動周波数の変化
数とともに増加する. $M=0.50 \sim 0.60$ では, 一時的に周 波数が $1,700 \mathrm{~Hz}$ 程度から $1,000 \mathrm{~Hz}$ 程度に減少するが， こ の原因については，第 5 章で述べる .一方，タブを付けた 場合には, 弚の取付け位置により周波数変化の樣子が異な

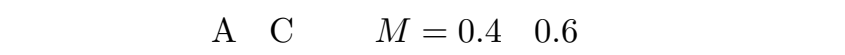
は $2,000 \sim 3,500 \mathrm{~Hz}$ となり, タブ無しの場合と比べて大幅 に増加する.さらに, タイプ A と B では, $M=0.60$ また は 0.64 を超えると急に周波数が減少する.また , タイプ C では他のタイプと異なり, 本解析の範囲では周波数の落ち 込みは見られず, $M=0.62$ までは $3,000 \mathrm{~Hz}$ 程度の周波数 であるが, 弚れ以降周波数は徐々に減少する.最後に, タ ブが最も後縁に近いタイプDでは, タブ無しの場合と周波 数レベルが類似しており， $M=0.60$ 近傍での周波数の落 ち込みも同樣である .

\section{5. 流れ場の詳細な検討}

5.1 時間平均化された流れ場 タブを取り付けた場合 に，1) タイプD を除いて抵抗か増加する $M=0.40,2$ ) いずれの取付け位置でも抵抗が減少する $M=0.62$, さら に3) (ずれの位置でもあまり抵抗か変化しない $M=0.75$ の 3 種類のマッハ数について, タブ無し, タイプ $\mathrm{B}$ および $\mathrm{D}$ を代表として, 時間平均流跡線を第 9 図に，また時間平
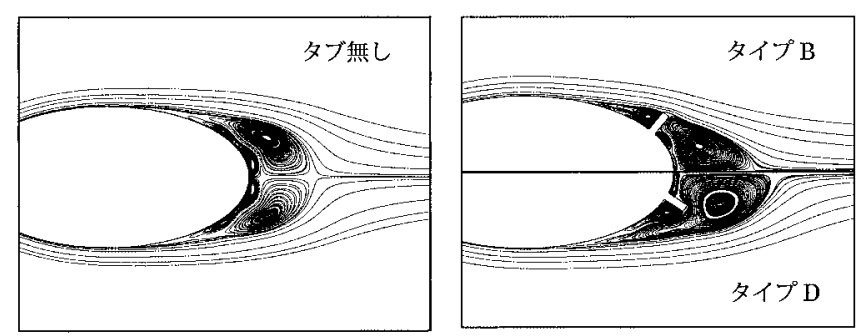

a) $\mathrm{M}=0.40$

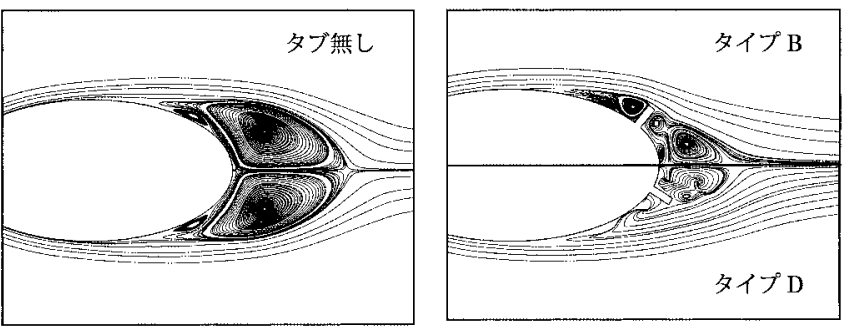

b) $\mathrm{M}=0.62$
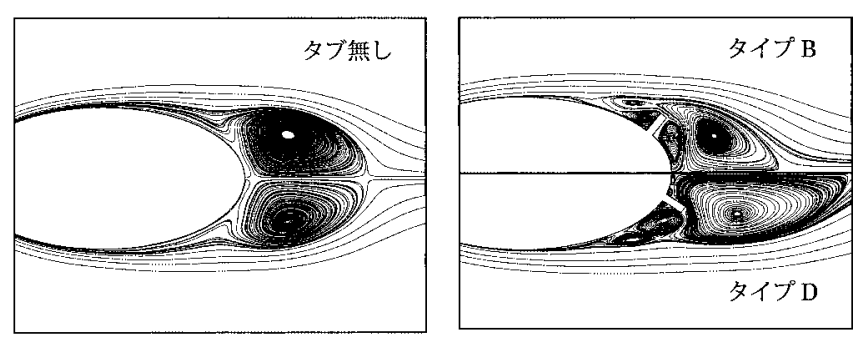

c) $\mathrm{M}=0.75$

第 9 図 時間平均流跡線 

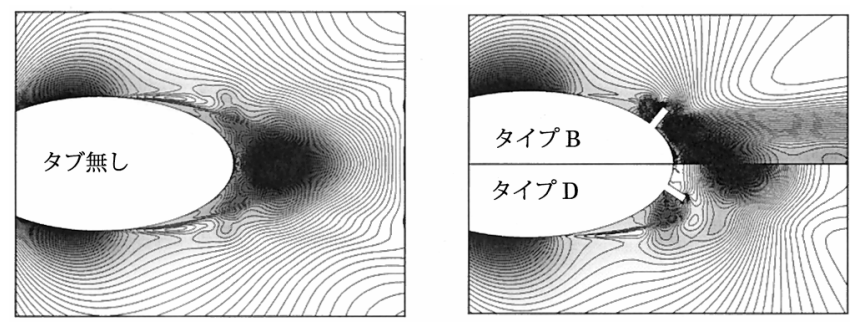

a) $\mathrm{M}=0.40$
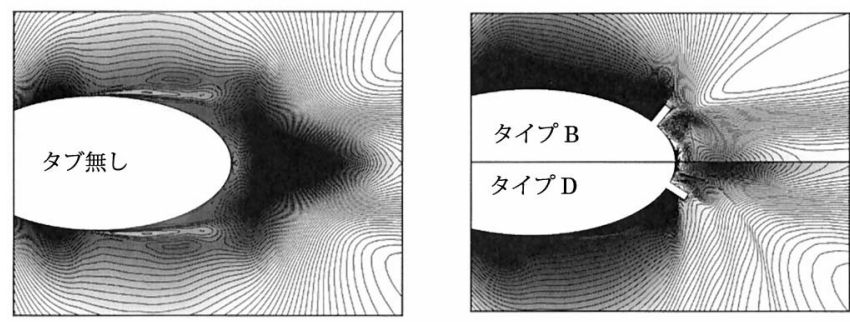

b) $\mathrm{M}=0.62$
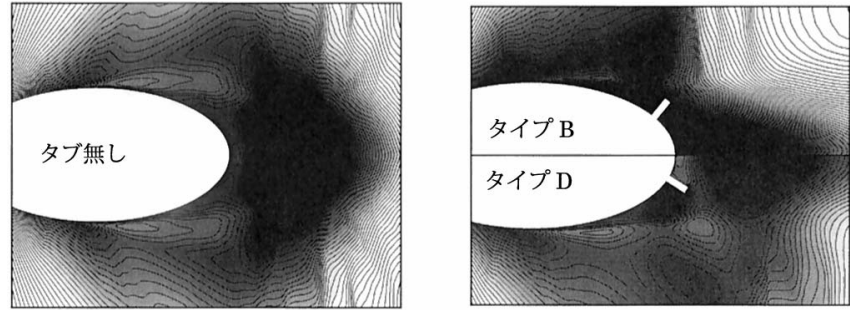

c) $\mathrm{M}=0.75$

第 10 図 時間平均圧力分布

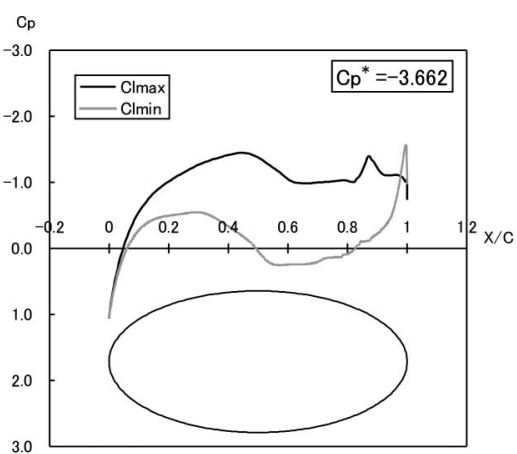

a) $\mathrm{M}=0.4$

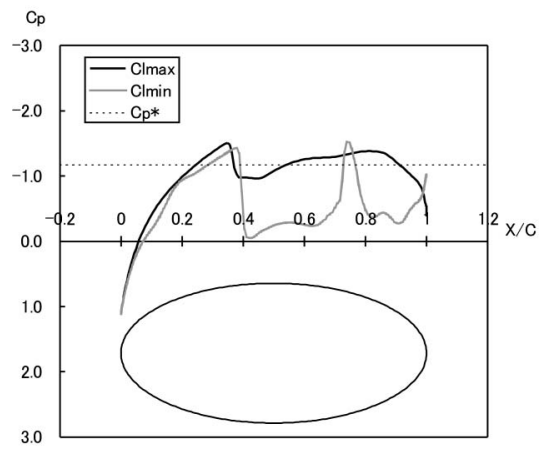

c) $\mathrm{M}=0.62$
均圧力分布を第 10 図に示す.

5.1 .1 流跡線 $M=0.40$ のタイプ B のタブでは (第 9 図 a), タブ後方の剝離渦はタブ無しと比べて翼の後ろ側 (タブの後ろ側) に回り込んでおり, 渦の大きさも増大して いる.一方，タイプDでは完全にタブが剥離流中に入り込 み, 剝離渦は翼の下流側に移動している .

$M=0.62$ になると， タブ無しの状態では翼後流側によ り大きな剥離渦か泩成されている(第 9 図b) .この流れに， タイプ B のタブを入れると，楕円翼中間点を過ぎた流れは タブの直前で剥離渦を生じ，光の外側ではより流線形に近 い形状の滑らかな流れ（言い換えれば細長比が大きな物体 まわりの流れ）となる . タブの後流では，タブ無しの場合 と比べて剥離渦はかなり小さくなっている . タイプDにつ いても，同樣の傾向である .

$M=0.75$ では, タイプ B では剝離渦の位置および大き さにあまり変化は見られないが, タイプ D の場合には, 剝 離渦はタブによって後方に押し出されている(第 9 図 c).

5.1.2 圧力分布 次に，圧力分布から流れ場を検討する。 第 10 図 a $M=0.40$ では, タイプ B のタブ直後に前 述した剥離渦の負圧が存在し，この負圧が抵抗を増加させ ている .一方, タイプ D ではタブ無しの場合と比べて後流 の負圧領域が翼から遠ざかり, 弚の結果, 抵抗が減少して いる .

$M=0.62$ になると, タイプ B の翼面上後半で気流の加 速と思われる負圧が発生し，抵抗増大を予想させるが, 翼 後方ではタブ無しで見られた剥離渦の負圧領域がほとんど

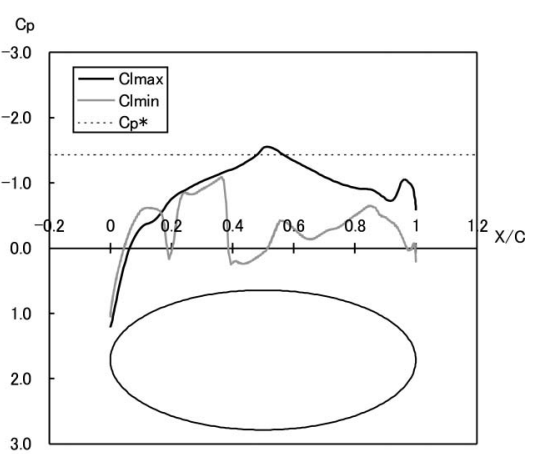

b ) $\quad \mathrm{M}=0.58$

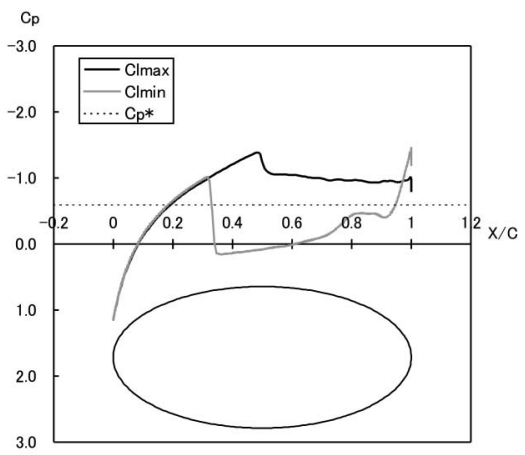

d) $\quad \mathrm{M}=0.75$

第 11 図 最大揚力時と最小揚力時での圧力分布 (タブ無し) 
見られず,ベース抵抗低減につながっている（第 10 图 b)， また , タイプ D の場合でもタイプ B とほぼ同じである .

$M=0.75$ になると, タイプ B ではタブ無しの場合とほ ぼ同じ位置に後流の負圧が発生している (第 10 图 c).し かし, タイプD ではタブの前方に負圧が発生し，また翼後 方の剝離渦が翼から遠ざかり，抵抗が減少している。

以上のことから，タブを取り付けて抵抗を低減させる流 れ場の特徵は，1) タブの前方に渦を作り推力を発生させる， 2) タブの後方では翼からの剝離渦をできる限り弱める，あ るいは翼から遠ざけることである . 本解析で使用した，ほ とんどのタブ取付け位置では, マッ八数が $0.5 \leqq M \leqq 0.75$ の範囲で抵抗低減を達成している。

\section{2 時間変動する流れ場}

5.2.1 タブ無しの場合 タブ無しの場合の圧力分布の時 間変動を見るために，揚力が最大および最小となる場合の 翼上面の圧力分布をマッ八数ごとに示す (第 11 図).第 11 図 a $M=0.40$ では上面の圧力分布は翼前縁近傍から翼 全体に渡り変化し，揚力係数の変動が大きい．しかし, 第 11 図 b〜d に示すように, マッ八数か増加し翼面上圧力か臨 界圧力係数 $\left(C p^{*}\right)$ より低い超音速領域が発生すると, 光の 性質上翼後流の擾乱が翼前半部まで基本的には到達しなく なる. 帝の結果, 翼前半部の圧力変化は小さくなり, 翼後半 部のみで衝撃波の移動により圧力か湾化する.このように， マッ八数か増加すると, 翼面上圧力が変化する領域か限定 されるため, 揚力係数の変動が減少すると考えられる (第 7 図参照). 同じ理由により，揚力変動周波数は， $M=0.60$ 近傍を除いてマッ八数か増加するとともに, 増加する (第 8 図参照).

第 12 図には, 風洞試験で使用されるシュリーレン写真を 模擬して, タブ無しの場合での, 各マッ八数における密度 勾配の瞬間值分布を示す . 左側の列にある図が最大揚力時 の結果で，右側は最小揚力時である.まず, 第 12 図 a の $M=0.40$ では, 衝撃波の発生もなく翼後半部から周期的 にカルマン渦が放出されている.この時の周波数は第 8 図 より約 $1,400 \mathrm{~Hz}$ である.また，第 12 図 bの $M=0.58$ に なると, 衝撃波が翼面上に発生するようになり，カルマン 渦と連動して周期的な振動となっている.ただし，衝撃波 は上下面で対称な位置には現われず，上下面で交互に移動 する. 光のため, 周期的な動きは比較的遅い．これが，第 8 図の揚力変動周波数が一時的に減少する理由で, このと き衝撃波は光れほど強くはない，さらに，マッ八数か増加 し,第 12 図 cの $M=0.62$ となると, 衝撃波が上下面でほ ほ対称な位置で移動するようになり，短い周期の現象とな る.これにより,第 8 図のタブ無しの变動周波数が再度増 加する.また，衝撃波も強くなる. 第 12 図 $\mathrm{d} の M=0.75$ となると, 衝撃波はより一層強くなるが, 弚の位置はあま り大きくは移動しない，一方，衝撃波の根元から放出する 剝離渦の大きさは小さく，短い周期で放出される．弚のた め, 变動周波数も再び $2,000 \mathrm{~Hz}$ 程度 (第 8 図参照) に増加 する. また， $M=0.75$ では衝撃波による剝離が支配的と なり, 衝撃波の根元から直線的に後流へ剝離せん断層が放
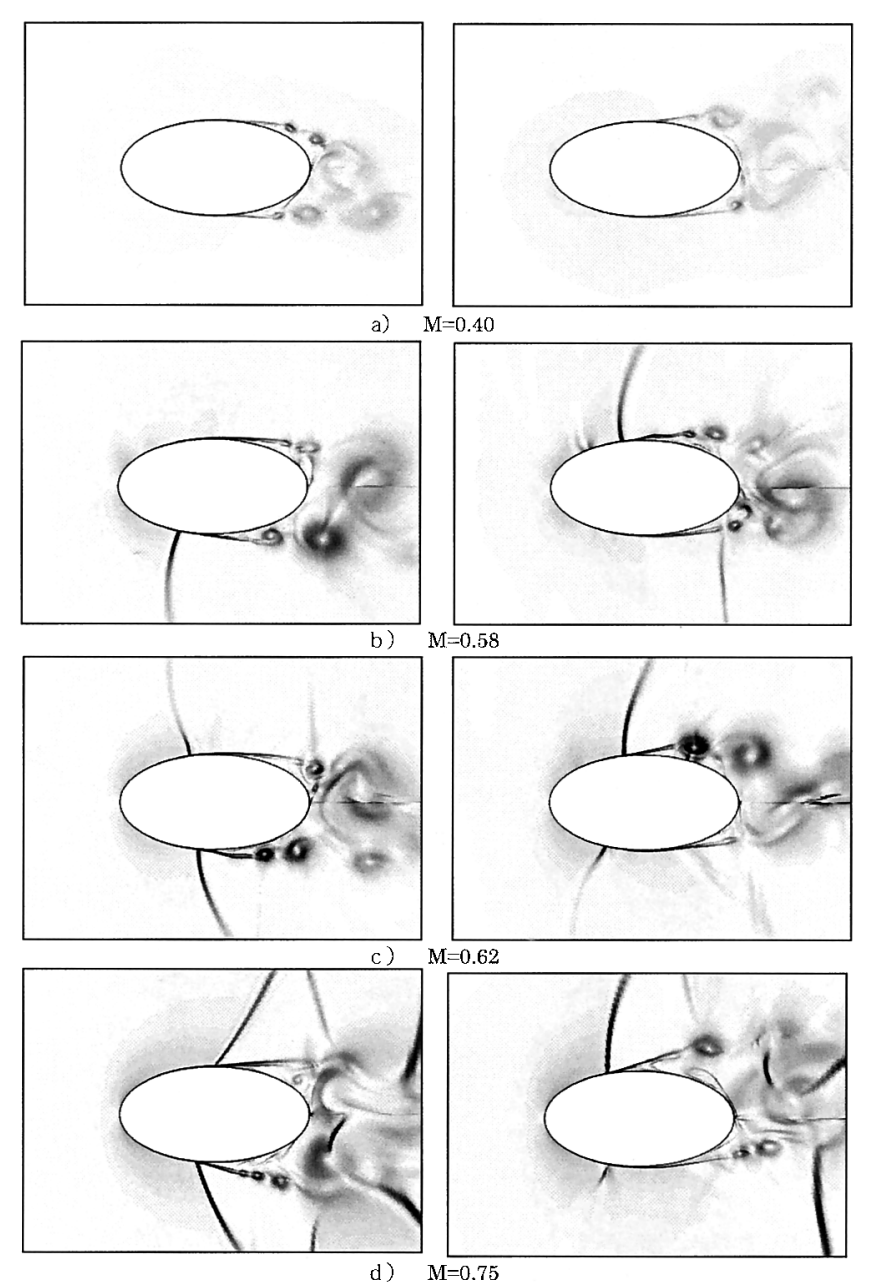

第 12 図 密度勾配の時間变化 (タブ無し, 左側 : 最大揚力時, 右側 : 最小揚力時)

出されている．

5.2.2 タブの効果 次に, タブを取り付けた場合の圧力 分布の時間変動を見るために，揚力が最大および最小とな る場合の翼上面の圧力分布を示す (第 13 図) .ここでは， タブの効果が大きい $M=0.62$ の場合について論ずる. タ ブ無しの場合，第 11 图 c からわかるように, コード長の 約 40\%位置から後方で衝撃波が移動し, 大きな揚力変動が 見られる。一方, タイプ A と B では, 強い衝撃波が観察 されず, 揚力変動もタブ近傍に限られる.また, タイプ C では, 衝撃波がコード長約 40〜 50\%位置の間て移動してい る、ちなみに, タイプDはタブ近傍では異なるが, 基本的 にはタブ無しの場合と類似した圧力分布となっている．

また，タブがある場合の密度勾配の瞬間值の分布を第 14 図に示す.第 12 図と同樣に, 左側の列が揚力最大時で, 右 側の列が揚力最小時である. 強い衝撃波が翼面上を前後に 移動するタブ無しの場合と異なり, タイプ A , B では複数 の弱い衝撃波群が翼面上に発生しており, 大きな揚力变動 は見られない (第 7 図参照).このタイプ A , B では, 翼中 間あたりで剥離したせん断層がちょうど後方のタブ付近に 到達し, 弚の後滑らかに下流に流れていく(タブ無しの場 合には上下面の後流渦が交互に成長してベース部を占領) . 


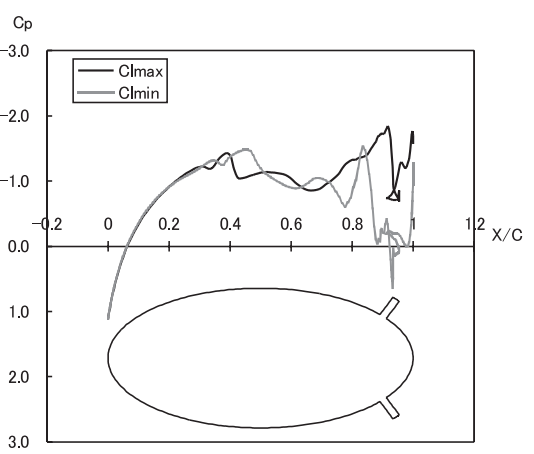

a) タイプ $\mathrm{A}$

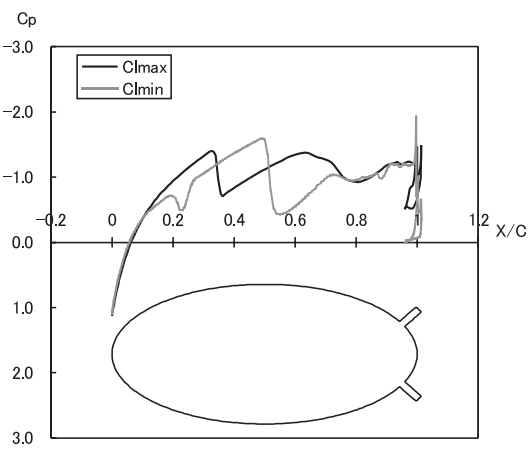

c）タイプ C

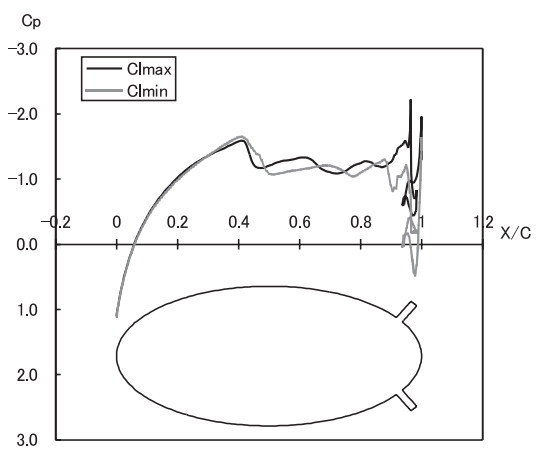

b) タイプ B

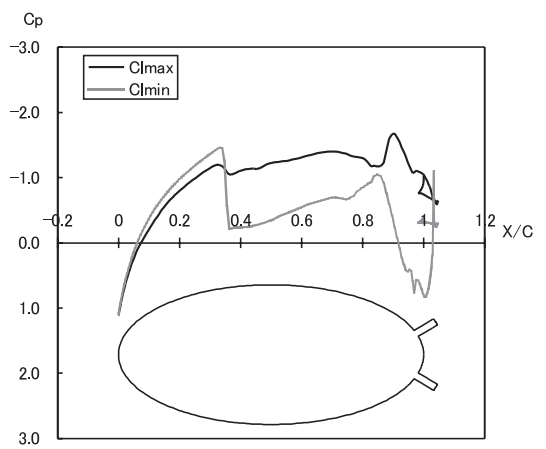

d）タイプ D

第 13 図 最大揚力時と最小揚力時での圧力分布 $(M=0.62)$

このとき，流線はあまり大きな曲率を持たないので，衝撃 波の発生も少ない (これが仮想形状効果の一つの特徵). こ れに比べて, タイプCの場合は, タブ無しの場合 (周波数 $1,800 \mathrm{~Hz}$ 程度) と比へて , 取り付けたタブの影響で翼面上 の衝撃波が翼後半部まで移動しない (第 14 図 c 参照) た め, 揚力変動も小さく, また変動周波数も $3,000 \mathrm{~Hz}$ 程度と 比較的高い (第 8 図).また, タイプD では, これまでの結 果でも述べたように, タブが後縁に近いためタブの影響が 小さい. 兴のため, タブ無しの場合と同樣な流れのパター ンを示している.

これまで, 抵抗および揚力変動の変化と流れ場との関連 について述べてきたが , これらをまとめると以下のように なる。

（1）タブが無い場合の楕円翼の特性において, 揚力変動 に関しては，マッ八数を増加すると翼前半部の圧力分布の 変化は小さくなり, 翼後半の圧力変動のみで揚力変動が発 生する. 兴のため, マッ八数か増加すると揚力係数の変動 は減少する.一方, 周波数に関しては, 上下面で発生する 衝撃波の位相により異なる. 低マッ八数では $1,400 \mathrm{~Hz}$ 程度 で, これはカルマン渦による振動と考えられる.中程度の マッ八数 $(M=0.58)$ では, 翼の上下面で交互に衝撃波が 発生し, 周波数は若干減少する. $M=0.62$ になると, 翼 上下面で同位相で衝撃波が発生し，周波数が再び $2,000 \mathrm{~Hz}$ 程度に上昇する.さらにマッ八数か増加すると，衝撃波と 境界層の干渉か強くなり，衝撃波の根元から発生する剝離
渦の大きさは小さくなり，周波数はさらに増大する .

(2) 今回採用した 4 種類のタブ取付け位置のどの場合で も, $M=0.60$ 付近で抵抗が低減されることがわかった. 乥 のとき, タブがあることにより, 剝離渦は翼後方に押し出 され渦による負圧が減少し，ベース抵抗が低減される．ま た，仮想形状効果として流れはタブを滑らかに飛び越えて 行く. 逆に, タイプ Bで $M=0.40$ の場合のように , タブ の下流側に大きな剝離渦が捕獲されると抵抗は増加する .

(3) 一方, 揚力変動の振幅に関しては, 今回使用した 4 種類のタブ取付け位置は，いずれも効果を示した . 特にタ イプ A , B , C では揚力変動がかなり減少し, $M=0.60$ 付近での揚力変動はタブ無しの場合の約 $1 / 6$ となる.これ は, タブを取り付けることにより, 翼後半の流線が翼に沿 わず直線的となる (仮想形状効果) ため, 衝撃波の発生が 抑えられるからである. また，周波数特性もこの仮想形状 効果により，カルマン渦の明確な周期性が見られず，周波 数は全体的に高くなっている.

$$
\text { 6. ま め }
$$

本研究では, 2 次元楕円翼を対象物体として, マッハ数 が増加すると, 翼後流のカルマン渦の他に, 翼面上に衝撃 波が発生し, 揚力変動が生じる現象を CFD 解析から捕ら えることができた．また，後縁付近に取り付けたタブによ り流れを制御し，抵抗低減と揚力変動の抑制が可能である ことが明らかになった . 特に, 本研究で採用したいずれの 

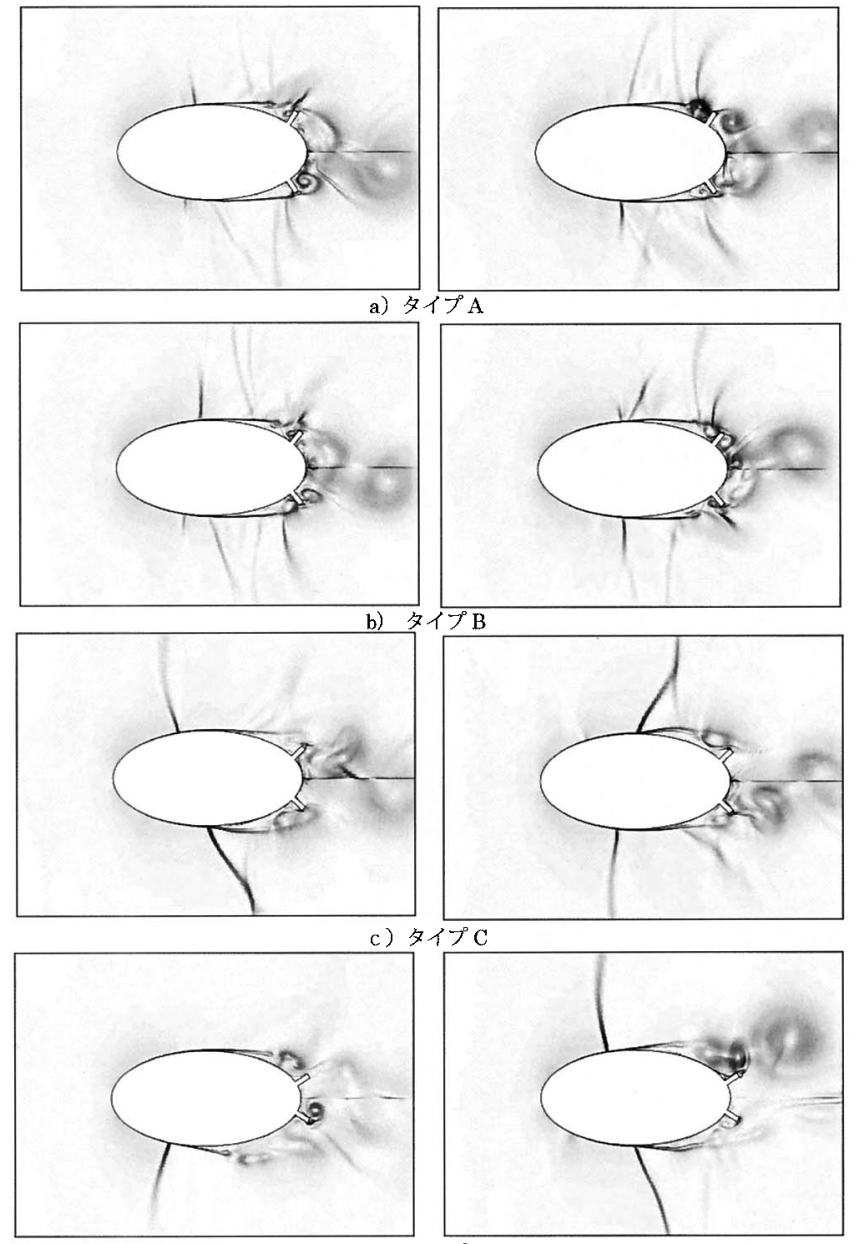

d) タイプD

第 14 図 密度勾配の時間変化 $(M=0.62$, 左側 : 最大揚力時, 右側 : 最小揚力時)

タブ位置でも, $M=0.60$ 近傍では抵抗と揚力変動の両方 を低減できる．これは, タブを取り付けることにより生じ る仮想形状効果で, これにより衝撃波か溺められるためで ある
本研究で明らかとなったタブの効果は, 航空宇宙機器の 実機設計への適用に有効であり，実機構造の強度等を考慮 した現実的なタブの開発が期待される .

本研究を実施するにあたり，菱友計算（株）鈴木康司氏 に多大な御協力を頂き，ここに感謝の意を表します．また， $\mathrm{CFD}$ 解析検証のための風洞試験を実施するにあたり，名古 屋大学 松野 隆氏，新川智英氏に御支援を賜り，感謝致し ます．

\section{参 考 文 献}

1) Roshko, A.: On the Drag and Shedding Frequency of Bluff Cylinders, NACA TN 3169, 1954.

2) Apelt, C. J., West, G. S. and Szewczyk, A. A.: The Effects of Wake Splitter Plates on the Flow Past a Circular Cylinder in the Range $10^{4}<R<5 \times 10^{4}$, J. Fluid Mech., 61 (1973), pp. 187-198.

3) Layukallo, T.: Control of Flow Separation on TwoDimensional Bodies at Transonic Speed, Doctor Thesis, Department of Aerospace Engineering, Nagoya University, 2002.

4) ラユカロトンビ, 中村佳朗 : Suppression of Flow Separation on a Circular Cylinder in Transonic Flows, 第 32 回流体力学講 演会講演集，2000, pp. 251-254.

5）新川智英, ラユカロトンビ, 中村佳朗 : 楕円柱まわりの遷音速バ フェツティングと炎の抑制，第 41 回流体力学会年会講演集 , 2002, pp. 98-99.

6) Fujii, K. and Obayashi, S.: High-Resolution Upwind Scheme for Vortical-Flow Simulations, J. Aircraft, 26 (1989), pp. 1123-1129.

7) Baldwin, B. S. and Lomax, H.: Thin Layer Approximation and Algebraic Model for Separated Turbulent Flows, AIAA Paper 78-257, 1978.

8) Degani, D. and Schiff, B. L.: Computation of Turbulent Supersonic Flows around Pointed Bodies Having Crossflow Separation, J. Comput. Phys., 66 (1986), pp. 173-196.

9) Layukallo, T. and Nakamura, Y.: Flow Stabilization in a Transonic Wind Tunnel with a Second Throat, J. Aircraft, 37 (2000), pp. 229-237.

10) Hoerner, F. S.: Fluid-Dynamic Drag-Practical Information on Aerodynamic Drag and Hydrodynamic Resistance, Published by Author, 1958.

11) Choi, J.-H. and Lee, S.-J.: Ground Effect of Flow around an Elliptic Cylinder in a Turbulent Boundary Layer, J. Fluids Struct., 14 (2000), pp. 697-709. 